\title{
H. Kesimpulan
}

Berdasarkan uraian pada pembahasan di atas, maka dapat disimpulkan beberapa hal, di antaranya:

1. Pembelajaran mahārah al-kitābah bagi mahasiswa merupakan keterampilan yang penting untuk dilatihkan agar mereka mumpuni dalam menghasilkan karya tulis dengan bahasa asing. Hal ini mengingat bahwa bahasa Arab adalah bahasa agama dan bahasa internasional.

2. Perkembangan zaman telah memberikan peluang bagi para dosen untuk mengajarkan dan melatihkan bahasa Arab, khususnya mahārah al-kitābah dengan memadukan antara pertemuan di dalam kelas secara langsung (face to face) dengan pemanfaatan teknologi yang tidak asing bagi mahasiswa, seperti: email, whatsapp, atau facebook. Perpaduan antara pertemuan langsung di kelas dengan pemanfaatan teknologi merupakan strategi pembelajaran yang disebut dengan blended learning.

3. Pertemuan secara langsung antara mahasiswa dan dosen di dalam kelas tidak dapat ditinggalkan, karena bagaimana pun dengan pertemuan akan dapat memperjelas hal-hal yang belum diketahui. Dalam face to face, dosen lebih menjadi fasilitator. Sedangkan penggunaan instrumen blended learning dijadikan media pembelajaran yang dimanfaatkan secara maksimal untuk membantu pembelajaran agar lebih efektif dan efisien serta agar tujuan pembelajaran dapat tercapai sesuai harapan. 


\section{DAFTAR PUSTAKA}

\section{Buku}

Ainin, M. 2006. Evaluasi dalam Pembelajaran Bahasa. Malang: Misykat.

Efendi, Ahmad Fuad. 2012. Metodologi Pengajaran Bahasa Arab. Malang: Misykat.

Fakhrurrozi, Aziz dan Erta Mahyudin. 2012. Pembelajaran Bahasa Arab. Cet. Ke-2 Jakarta Pusat: Direktoral Jenderal Pendidikan Islam Kementerian Agama.

Hamid, Abdul, dkk. 2008. Pembelajaran Bahasa Arab; Pendekatan, Metode, Strategi, Materi, dan Media. Malang: UIN-Malang Press.

Hermawan, Acep. 2011. Metodologi Pembelajaran Bahasa Arab. Bandung: Remaja Rosdakarya.

Kunandar. 2011. Langkah Mudah Penelitian Tindakan Kelas Sebagai Pengembangan Profesi Guru. Jakarta: PT. Raja Grafindo Persada.

Mustofa, Bisri dan Abdul Hamid. 2011. Metode \& Strategi Pembelajaran Bahasa Arab, Malang: UIN-Malang Press.

Mustofa, Syaiful. 2011. Strategi Pembelajaran Bahasa Arab Inovatif, Malang: UINMalang Press.

Rusman. 2011. Pembelajaran Berbasis Teknologi Informasi dan Komunikasi, Jakarta: PT Raja Grafindo Persada.

Syah, Muhibbin. 2010. Psikologi Pendidikan dengan Pendidikan Baru, Bandung: PT Remaja Rosdakarya.

Taufik. 2011. Pembelajaran Bahasa Arab MI, Surabaya: PMN.

\section{Jurnal dan Makalah}

Hayati, Nur. 2018. Pengelolaan Pembelajaran Melalui Blanded Learning dalam Meningkatkan Receptive Skill Peserta Didik di Pondok Pesantren. Jurnal: Studi Keislaman dan Ilmu Pendidikan Volume 6, Nomor 2, November 2018.

Sa'diyah, Halimatus. 2018. Ta'lim Mahārah al-Kitābah bi Wasilah Watsab. Jurnal: Ta'lim al-Lughah al-`Arabiyah, Malang: UIN Maulana Malik Ibrahim Malang.

Zuhdi, Halimi. 2017. Peningkatan Kompetensi Pembelajaran Bahasa Arab BSA UIN Malang. Makalah: Workshop di Fakultas Humaniora, Malang: UIN Maulana Malik Ibrahim Malang. 


\title{
INTEGRASI PENDIDIKAN KARAKTER DALAM PEMBELAJARAN KETERAMPILAN MEMBACA ARAB
}

\author{
Nur Toifah \\ Program Khusus Perkuliahan Bahasa Arab \\ Universitas Islam Negeri Maulana Malik Ibrahim Malang \\ Email:nur2toifah@gmail.com
}

\begin{abstract}
The current of globalization is fast entering the community, especially among teenagers. The influence of globalization on young people is so strong. This influence has demoralized and moral decadence experienced by students in Indonesia. Until now, the Indonesian nation is still faced with a number of problems, especially issues related to morals. To produce a superior generation, it is not unusual for a teacher to educate and instill morality that begins in the souls of students, this can be done by developing character education in the educational environment, namely by integrating character values in learning, including reading learning Arab. Integration of character education in Arabic reading learning is outlined in learning strategies, such as broken text and peer teaching learning strategies, in which the strategies are active, innovative, and fun. While the character values developed in Arabic reading learning are religious, honest, tolerance, independence, democratic, curiosity, communicative/friendly, social care, responsibility, discipline, caring for the environment and respecting achievement.
\end{abstract}

Kata Kunci: Integrasi, Pendidikan Karakter, Pembelajaran Keterampilan Membaca Arab

\section{A. Pendahuluan}

Secara umum pembelajaran bertujuan untuk mengembangkan potensi peserta didik agar menjadi manusia yang beriman dan bertakwa kepada Tuhan Yang Maha Esa, berakhlak mulia, sehat, berilmu, cakap, kreatif, mandiri, dan menjadi warga negara yang demokratis serta bertanggung jawab (Hafid, dkk, 2013: 45).

Undang-undang tentang Sisdiknas mengedepankan pembentukan karakter peserta didik, sehingga peserta didik diharapkan memiliki nilai-nilai karakter mulia yang dijadikan sebagai dasar dalam bertindak. Dengan adanya tujuan pembelajaran tersebut, diharapkan demoralisasi dan dekadensi moral tidak 
terjadi. Tetapi dalam realita, hal tersebut masih terjadi, yang dibuktikan dengan berbagai data tentang demoralisasi dan dekadensi moral yang dialami oleh pelajar di Indonesia. Berbagai macam tindakan kriminal dan kenakalan remaja yang dilakukan oleh generasi muda terpelajar masih mewarnai media massa baik cetak maupun elektronik. Oleh karena itu, tugas setiap pengajar adalah membenahi dan meluruskan perilaku-perilaku yang salah dan tidak baik tersebut dengan melakukan internalisasi nilai-nilai karakter di setiap mata pelajaran, termasuk materi bahasa Arab.

Dalam pembelajaran bahasa Arab, terdapat empat keterampilan bahasa yang dipelajari, keterampilan mendengar, keterampilan membaca, keterampilan berbicara, dan keterampilan menulis. Selain itu, terdapat dua macam kemampuan berbahasa Arab, yaitu kemampuan reseptif, yang mana kemampuan tersebut untuk memahami pembicaraan orang lain dan memahami bacaan. Yang termasuk kemampuan ini adalah keterampilan mendengar dan keterampilan membaca. Yang selanjutnya adalah kemampuan produktif, yaitu kemampuan menggunakan bahasa sebagai alat komunikasi, baik secara lisan maupun tulisan. Kemampuan ini mencakup keterampilan berbicara dan keterampilan menulis. Keutuhan keempat keterampilan tersebut harus bersinergi dengan baik dan benar antara satu dengan yang lainnya (Izzan, 2007: 86).

Bertalian dengan kemampuan reseptif dalam pembelajaran bahasa Arab, tidak akan bisa terlepas dengan apa yang dinamakan keterampilan membaca, yang mana ia adalah memindahkan simbol tertulis ke dalam bahasa ujaran atau bunyi. Ia merupakan kemampuan mengenali dan memahami isi sesuatu yang tertulis dengan melafalkan atau mencernanya di dalam hati. Ada beberapa unsur yang terlibat dalam membaca, yaitu makna sebagai isi bacaan, kata sebagai unsur yang membawakan makna, dan simbol tertulis sebagai unsur visual.

\section{B. Makna Pendidikan Karakter}

Kata character diambil dari bahasa Yunani charassein, yang mempunyai makna to engrave (melukis, menggambar, memahat), sebagaimana orang yang melukis kertas, memahat batu atau mengukir. Berdasarkan makna tersebut, karakter selanjutnya diartikan sebagai lambang atau ciri yang khusus, oleh karenanya memunculkan satu anggapan bahwa karakter berarti pola perilaku yang bersifat individual, yang merupakan keadaan tingkah laku atau akhlak seseorang. Gaya, sifat, ciri, maupun karakteristik adalah sebuah karakter yang 
dimiliki seseorang yang berawal dari pembentukan atupun tempaan yang diperoleh melewati lingkungan yang ada di sekitar (Suyadi, 2015: 5).

Seseorang mempunyai dua sifat karakteristik, yaitu sifat yang dibawa semenjak lahir dan sifat bentukan yang dialami setelah dewasa. Dari sifat bentukan inilah yang selanjutnya mendasari pemikiran bahwa karakter dapat dibuat, dibingkai, dan diatur dengan pendidikan. Akan tetapi tidak menutup kemungkinan pula, selama proses pendidikan karakter yang bersifat bawaan juga akan terbentuk dengan baik.

Sedangkan pendidikan karakter adalah sebuah tindakan sadar atau tindakan yang disengaja guna menolong peserta didik sampai dia dapat memahami, mencermati, dan mengamalkan nilai-nilai moral yang mendasar. Di dalamnya termuat tindakan-tindakan yang dilakukan oleh pihak sekolah termasuk guru, hingga yang dilakukan bersama-sama dengan orang tua dan semua masyarakat untuk menolong peserta didik, agar menjadi atau memperoleh sifat simpati, percaya diri, serta penuh dengan rasa tanggung jawab. Nilai karakter atau moral tersebut akan berkembang dengan baik bila mereka diberi cukup kesempatan untuk "memainkan peran" dalam suatu kejadian, dengan melihat peristiwa, permasalahan dari perspektif yang berbeda, dan memasukkan diri dalam situasi orang lain (Adisusilo, 2013: 127).

\section{Nilai-Nilai Karakter yang Diintegrasikan dalam Pembelajaran}

Sebagai pendidik agung, misi utama Rasulullah Saw. adalah pendidikan karakter, di mana dalam agama Islam dikenal dengan istilah akhlaq al-karimah. Rasulullah Saw. bersabda, "Sesungguhnya aku diutus (oleh Allah SWT) hanya untuk menyempurnakan dan mewujudkan akhlak mulia". (HR. Al-Bukhari dan Muslim). Di samping tugas menyempurnakan akhlak, Rasul akhir zaman tersebut juga mempunyai sifat empat karakter yang mulia, yaitu: shidiq (jujur), amanah (dapat dipercaya), tabligh (menyampaikan kebenaran), dan fathānah (cerdas). Sebagai manusia sempurna yang hidup di muka bumi, beliau telah memberikan contoh keteladanan bagaimana membangun sebuah karakter bangsa dan mempengaruhi dunia (Saleh, 2012: 01).

Pendidikan karakter dimaksudkan untuk membangun karakter pada diri peserta didik, dan adanya karakter tersebut adalah dengan mengimplementasikan nilai-nilai moral yang baik, dalam konteks global dan juga konteks budaya bangsa Indonesia. Karena proses pembelajaran karakter 
yang harus diwajibkan sangat beragam, maka nilai-nilai karakter tidak dibatasi dengan satu nilai pilar karakter semata. Nilai karakter yang ditanamkan berlaku secara universal dalam berbagai ruang lingkup agama, budaya, dan kehidupan sosial masyarakat, baik lokal ataupun internasional. Oleh sebab itu, berbagai jenis karakter yang akan ditanamkan dan diajarkan dalam proses pembelajaran harus diketahui oleh seorang guru, tidak hanya berkonsentrasi atau terjebak dalam satu pilar karakter saja.

Berkaitan dengan berbagai jenis nilai budaya yang berorientasi karakter di Indonesia, Kemendiknas (2010) membentuk 18 karakter yang wajib ditanamkan pada diri peserta didik sepanjang proses pembelajaran. Tentu saja kedelapan belas nilai karakter tersebut bisa dikembangkan lagi dengan asuhan, kreativitas, dan keteladanan yang baik dari seorang guru.

Berikut ini 18 butir nilai-nilai pendidikan karakter yang dirumuskan oleh Kemendiknas sebagaimana tercantum dalam buku Pengembangan Pendidikan Budaya dan Karakter Bangsa, yang dirumuskan melalui Badan Penelitian dan Pengembangan Pusat Kurikulum (Kementerian Pendidikan Nasional, 2010) yaitu:

1. Religius, yaitu melaksanakan ajaran agama (aliran kepercayaan) yang diyakini serta menaati dan memahami norma-norma ketaatan dan kepatuhan di setiap ajaran agama sebagai pedoman hidup, termasuk dalam hal ini adalah hidup rukun dan berdampingan antar sesama masyarakat dan memberikan kesempatan untuk beribadah di masing-masing tempat ibadah sebagai cermin sikap toleransi terhadap pelaksanaan ibadah yang diyakini antar pemeluk agama.

2. Jujur, yaitu selaras dengan pengetahuan, perkataan dan perilaku (mengetahui yang benar dan melakukan yang benar) yang mencerminkan bentuk sikap dan tingkah laku yang baik, sehingga menjadikan peserta didik sebagai subyek yang dapat dipercaya.

3. Toleransi, yaitu sikap dan tingkah laku yang menggambarkan penghargaan terhadap keberagaman agama, aliran kepercayaan, suku, adat, bahasa, ras, etnis, pendapat, dan hal-hal lain yang berbeda dengan dirinya secara sadar dan terbuka, serta dapat hidup tenang di tengah perbedaan.

4. Disiplin, yaitu kebiasaan dan perbuatan yang terus menerus dilakukan terhadap segala bentuk peraturan atau tata tertib yang berlaku di tengahtengah masyarakat. 
5. Kerja keras, yaitu usaha yang dilakukan untuk menunjukkan upaya secara sungguh-sungguh (berjuang hingga titik darah penghabisan) dalam menuntaskan bermacam-macam tugas, permasalahan, pekerjaan, dan lainlain dengan sebaik-baiknya.

6. Kreatif, yaitu sikap dan perbuatan yang melukiskan inovasi dalam aneka ranah untuk mengatasi persoalan, sehingga selalu mendapati metodemetode baru, bahkan hasil-hasil baru yang lebih baik dari sebelumnya.

7. Mandiri, yaitu sikap dan perbuatan yang tidak menggantungkan bantuan orang lain dalam memecahkan berbagai tugas maupun masalah. Akan tetapi hal ini tidak berarti tidak boleh kerja sama secara bersama-sama, melainkan tidak boleh melemparkan tugas dan tanggung jawab kepada orang lain.

8. Demokratis, yaitu persamaan hak dan kewajiban yang secara adil dan merata antara diri seseorang dan orang lain diberikan kebebasan dalam mengutarakan aspirasinya.

9. Rasa ingin tahu, yaitu rasa penasaran dan keingin tahuan terhadap segala sesuatu yang dapat dilihat, didengar, dan dipelajari secara lebih mendalam yang tercermin dalam pola berpikir, bersikap, dan bertingkah laku.

10.Semangat kebangsaan atau nasionalisme, yaitu sikap dan tindakan yang dilakukan untuk kepentingan bangsa dan negara di atas kepentingan pribadi atau individu dan golongan.

11.Cinta tanah air, yaitu sikap dan perilaku yang mencerminkan rasa bangga, setia, peduli dan penghargaan yang tinggi terhadap bahasa, budaya, ekonomi, politik, dan sebagainya, sehingga tidak mudah menerima tawaran bangsa lain yang dapat merugikan bangsa sendiri.

12.Menghargai prestasi, yaitu sikap terbuka terhadap prestasi orang lain dan mengakui kekurangan diri sendiri tanpa mengurangi semangat berprestasi yang lebih tinggi.

13.Komunikatif, yaitu senang bersahabat atau proaktif, yakni sikap dan tindakan terbuka terhadap orang lain melalui komunikasi yang santun sehingga tercipta kerja sama secara kolaboratif dengan baik.

14.Cinta damai, yaitu sikap dan perilaku yang mencerminkan suasana damai, aman, tenang, dan nyaman atas kehadiran dirinya dalam komunitas atau masyarakat tertentu.

15.Gemar membaca, yaitu kebiasaan dengan tanpa paksaan untuk menyediakan waktu secara khusus guna membaca berbagai informasi, baik berupa buku, 
jurnal, majalah, koran, dan sebagainya, sehingga menimbulkan kebijakan bagi dirinya.

16.Peduli lingkungan, yaitu sikap dan tindakan yang selalu berupaya menjaga dan melestarikan lingkungan sekitar.

17.Peduli sosial, yaitu sikap dan perbuatan yang mencerminkan kepedulian terhadap orang lain maupun masyarakat yang membutuhkannya.

18.Tanggung jawab, yaitu sikap dan perilaku seseorang dalam melaksanakan tugas dan kewajibannya, baik yang berkaitan dengan diri sendiri, sosial, masyarakat, bangsa, negara maupun agama.

\section{Konsep Dasar Pembelajaran Membaca}

Membaca pada dasarnya mengandung dua aspek, yaitu mengubah lambang tulis menjadi bunyi, dan menangkap arti dari seluruh situasi yang dilambangkan dengan lambang tulis tersebut. Kemampuan membaca juga dapat diwujudkan dalam bentuk membaca keras maupun dalam hati, mem $\neg$ baca keras menunjukkan pemahaman terhadap apa yang dibaca, dan ia lebih mudah diukur daripada membaca dalam hati.

Ada 3 jenis bentuk membaca, yaitu pertama membaca pemahaman, yang mana merupakan proses untuk mendapatkan informasi yang terkandung dalam teks bacaan untuk memperoleh pemahaman atas bacaan tersebut. Kedua yaitu membaca kritis, di mana membaca merupakan aktivitas yang dilakukan guna mengkritisi isi bacaan tersebut. Ketiga adalah membaca kreatif, ia dikatakan sebagai proses memperoleh informasi sebagai bahan pengembangan produk kreatif pascabaca. Berdasarkan beberapa pengertian membaca tersebut, jelaslah bahwa membaca pada prinsipnya dapat didefinisikan berdasarkan berbagai sudut pandang yang berbeda-beda. Dan pembaca yang baik adalah pembaca yang mampu berkomunikasi secara intim dengan bacaan, ia bisa bersedih, marah, bergembira, kagum, takut, ataupun rindu ketika membaca (Hermawan, 2014:144).

Membaca sebagai proses pada dasarnya adalah kegiatan yang dilakukan untuk mendapatkan arti atau makna dari kata-kata tertulis. Proses membaca sendiri meliputi proses visual, perseptual dan konseptual. Oleh sebab itu, membaca sering pula diartikan sebagai sebuah proses berpikir, sebab di dalam kegiatan membaca seorang pembaca berusaha mengartikan, menafsirkan, dan memperoleh informasi yang terkandung dari bahan bacaan. Membaca juga 
melibatkan penglihatan, gerak mata, pembicaraan batin, ingatan, pengetahuan mengenai kata yang dapat dipahami, dan pengalaman pembacanya.

Pembelajaran keterampilan membaca bukan hanya sekedar mengajarkan membaca, tetapi lebih dari itu peserta didik dianggap mampu memahami jika sudah mencapai beberapa indikator pencapaian keterampilan membaca. Indikator-indikator tersebut ada-lah (Mustofa, 2011: 162):

1. Peserta didik mampu membaca sebuah teks Arab dengan bacaan yang benar.

2. Peserta didik mampu memahami bacaan secara benar.

3. Peserta didik mampu menerjemahkan bacaan secara benar.

4. Peserta didik mengetahui kedudukan bacaan setiap kata dan bisa menceritakan ulang dengan memakai bahasanya sendiri.

\section{E. Orientasi Pembelajaran Membaca}

Setiap pembelajaran keterampilan bahasa mempunyai tujuan khusus, begitu juga pembelajaran keterampilan membaca Arab (mahärah al-Qirä'ah). Secara umum, target pembelajaran keterampilan membaca adalah peserta didik mampu membaca teks Arab dengan fasih, mampu menerjemahkan, dan mampu memahaminya dengan baik dan benar. Begitu juga terdapat tiga tujuan utama pembelajaran membaca, yaitu: (1) peserta didik mampu menikmati kegiatan membaca, (2) peserta didik mampu membaca dalam hati dengan kecepatan yang fleksibel, dan (3) peserta didik memperoleh tingkat pemahaman yang cukup atas isi bacaan (Abidin, 2015: 149).

Bertalian dengan target membaca tersebut, ada tujuan umum dalam pembelajaran keterampilan membaca, di antaranya yaitu:

1. Mengenali naskah tulisan suatu bahasa.

2. Memaknai tulisan yang menggunakan kosakata asing.

3. Memahami informasi yang dinyatakan secara eksplisit dan implisit.

4. Memahami makna konseptual.

5. Memahami nilai komunikatif dari suatu kalimat.

6. Memahami hubungan dalam kalimat, antar kalimat, dan antar paragraf.

7. Menginterpretasi bacaan.

8. Mengidentifikasi informasi penting dalam wacana.

9. Membedakan antara gagasan utama dan gagasan penunjang.

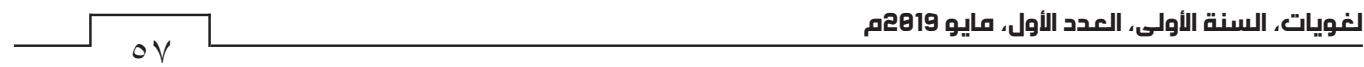


10.Menentukan hal-hal penting untuk dijadikan rangkuman.

Adapun tujuan khusus dari pembelajaran keterampilan membaca ini dikategorikan dalam tiga tingkatan berbahasa, yaitu tingkat dasar (pemula), tingkat menengah, dan tingkat atas (lanjut).

1. Tingkat Dasar (Pemula)

Pada tingkat dasar ini, tujuan pembelajaran keterampilan membaca adalah:

a. Mengenali lambang-lambang (simbol-simbol bahasa).

b. Mengenali kata dan kalimat.

c. Menemukan ide pokok dan kata-kata kunci.

d. Menceritakan kembali isi bacaan pendek.

2. Tingkat Menengah

Pada tingkat menengah ini, tujuan pembelajaran keterampilan membaca adalah:

a. Menemukan ide pokok dan ide penunjang.

b. Menceritakan kembali berbagai jenis isi bacaan.

3. Tingkat Atas (Lanjut)

Pada tingkat atas atau lanjut ini, tujuan pembelajaran keterampilan membaca adalah:

a. Menemukan ide pokok dan ide penunjang.

b. Menafsirkan isi bacaan.

c. Membuat inti sari bacaan.

d. Menceritakan kembali berbagai jenis isi bacaan.

\section{F. Macam-Macam Membaca}

Secara umum, kegiatan membaca dibagi menjadi dua, yaitu membaca nyaring (al-qirä'ah al-jahriyah) dan membaca dalam hati (al-qirā'ah al-shāmitah) (Hermawan, 2104: 143).

\section{Membaca nyaring (al-qirā'ah al-jahriyah)}

Membaca nyaring merupakan membaca dengan melafalkan atau menyuarakan simbol-simbol tertulis berupa kata-kata atau kalimat yang dibaca. Membaca nyaring perlu dilakukan dalam pembelajaran membaca, terutama kepada peserta didik tahap pemula. Pada tahap ini mereka harus dikenalkan kepada bunyi-bunyi huruf Arab dan dilatih pelafalannya. Seperti diketahui 
bahwa bahasa Arab memiliki karakteristik bunyi yang berbeda secara prinsipil dibandingkan dengan bunyi-bunyi huruf pada bahasa mereka. Jika mereka tidak dikenalkan dan sering dilatih pengucapannya secara benar, maka akan menjadi kendala pada belajar tahap selanjutnya. Pada tahap permulaan ini, pengajar sebaiknya lebih dahulu memperkenalkan kata-kata yang sudah banyak diserap oleh bahasa mereka. Hal ini dilakukan supaya mereka tidak mengalami kesulitan dalam awal pembelajaran membaca mereka. Selanjutnya pengajar memberikan contoh pengucapan kata-kata, yang kemudian dirangkai menjadi kalimat dan paragraf.

Dalam mengajarkan pembelajaran membaca nyaring, pengajar hendaknya memperhatikan beberapa hal, yaitu:

a. Dalam memulai kegiatan membaca, pengajar hendaknya memilih peserta didik yang bagus bacaannya. Hal ini dimaksudkan untuk percontohan bagi teman-temannya, juga akan turut memberikan semangat mereka untuk membaca. Sebaiknya pengajar memintanya untuk membaca di depan kelas, dan sesekali membagikan pandangan kepada teman-temannya saat membaca.

b. Hendaknya pengajar mampu menciptakan kelas yang turut serta menjadi pengoreksi kesalahan bacaan. Semua peserta didik harus memperhatikan bacaan temannya.

c. Tidak diperkenankan bagi seorang pengajar untuk meminta membaca terlalu lama, sebab hal tersebut akan cepat melelahkan. Demikian juga porsi waktu yang digunakan untuk membaca nyaring tidak terlalu lama, sehingga tidak menyita porsi waktu untuk mengajarkan keterampilan bahasa yang lain.

\section{Membaca dalam hati (al-qirā'ah al-shāmitah)}

Membaca dalam hati atau dikenal dengan membaca pemahaman, yang mana membaca dengan tidak menyaringkan bacaan simbol-simbol tertulis berupa kata-kata atau kalimat yang dibaca, melainkan hanya mengandalkan kecermatan eksplorasi visual. Tujuan membaca ini untuk menguasai isi bacaan, atau memperoleh informasi sebanyak-banyaknya tentang isi bacaan dalam waktu yang cepat. Membaca dalam hati ini merupakan keterampilan mendasar yang harus dikuasai oleh peserta didik dengan baik, sebab ia lebih efektif dalam memahami isi bacaan dibandingkan dengan membaca nyaring.

Kegiatan membaca diam ini akan menjadi efektif bila dilakukan dengan empat hal, yaitu: 
a. Memperluas jangkauan visual, kata-kata dalam bacaan.

b. Mengurangi pengulangan deteksi kata.

c. Menghindari deteksi kata terlalu lama.

d. Menghindari istirahat di tengah-tengah sebelum bacaan selesai.

\section{G. Internalisasi Pendidikan Karakter dalam Pembelajaran Membaca Arab}

\section{Pembelajaran membaca Arab dengan strategi Broken Text}

Strategi broken text merupakan salah satu strategi yang efektif dalam pembelajaran bahasa Arab, khususnya dalam pembelajaran membaca Arab. Strategi ini merupakan strategi yang sangat aktif dan kreatif, di mana peserta didik dituntut untuk berfikir logis dengan mengurutkan alur cerita atau bacaan yang sudah dipotong-potong. Ia juga sangat efektif untuk mengukur tingkat pemahaman peserta didik dari teks bacaan yang telah ditelaahnya.

a. Tahapan pembelajaran keterampilan membaca Arab dengan strategi broken text adalah:

1. Tahap pra membaca (pendahuluan)

Kegiatan yang dilakukan pengajar pada tahapan ini adalah:

a) Mengucapkan salam dan menyapa peserta didik dengan bertanya kabar mereka.

b) Mengajak peserta didik untuk berdoa sebelum belajar dan membaca beberapa ayat al-Qur'an atau membaca salah satu surat pendek dari juz 30.

c) Mengingatkan peserta didik bahwa pada saat itu akan belajar keterampilan membaca Arab.

d) Bertanya kepada beberapa peserta didik tentang pelajaran yang sudah dipelajari pada pertemuan sebelumnya.

e) Memberikan apersepsi dengan cara mengaitkan materi yang sudah dipelajari dengan materi yang akan dipelajari.

f) Menjelaskan topik dan tujuan pembelajaran, serta beberapa manfaat dari tema yang akan dipelajari dalam kehidupan peserta didik.

g) Menjelaskan kepada mereka bahwa akan belajar membaca Arab dengan strategi broken text atau mengurutkan potongan-potongan bacaan.

h) Menjelaskan kepada peserta didik bahwa mereka harus bersikap aktif dan kreatif untuk membaca teks yang berhubungan dengan tema. 
i) Setelah semua peserta didik paham dengan penjelasan pengajar, ia membagi peserta didik menjadi 4 atau 5 kelompok.

j) Pengajar meminta peserta didik untuk berkumpul dengan kelompoknya masing-masing.

k) Pengajar menjelaskan bahwa dalam strategi broken text ini, setiap anggota kelompok harus aktif membaca teks yang sudah dipotongpotong untuk diurutkan menjadi cerita yang urut dan sempurna.

1) Menyiapkan sebuah naskah cerita yang sudah dipotong-potong menjadi beberapa bagian.

m)Mengajak peserta didik untuk membaca basmalah dan memberikan apresiasi pada semuanya dengan bertepuk tangan.

2. Tahap membaca (kegiatan inti)

Pada tahapan membaca dengan strategi broken text ini, langkah-langkah yang harus dilalui oleh pengajar adalah:

a) Membacakan beberapa mufradāt yang belum diketahui oleh peserta didik dalam tema, dan menjelaskan maknanya.

b) Menanyakan kepada peserta didik tentang pemahaman mereka.

c) Meminta peserta didik untuk selalu membuka kamusnya jika terkendala dalam membaca teks.

d) Mengajak peserta didik untuk bersiap-siap memulai pembelajaran membaca Arab.

e) Membagikan potongan naskah kepada masing-masing kelompok.

f) Meminta kepada setiap peserta didik dalam kelompok untuk membaca teks secara bergantian.

g) Meminta kepada semua peserta didik untuk memahami potonganpotongan kalimat dalam kelompok mereka.

h) Memperhatikan antusiasme peserta didik, keaktifan dan kreativitas mereka.

i) Meminta kepada mereka untuk mengurutkan potongan-potongan kalimat tersebut.

j) Setelah kerja kelompok selesai, pengajar meminta masing-masing kelompok untuk mempresentasikan atau menyampaikan hasilnya ke depan kelas.

k) Memberikan kesempatan kepada kelompok lain untuk memberikan komentar atau pertanyaan. 
1) Memberikan evaluasi dan klarifikasi terhadap hasil kerja kelompok tersebut, sehingga terjadi kesamaan pemahaman materi.

m)Memberikan apresiasi kepada semua peserta didik karena sudah belajar dengan aktif, kreatif, dan semangat.

3. Tahap pasca-membaca (kegiatan penutup)

Pada tahapan ini, langkah-langkah yang dilakukan oleh pengajar adalah:

a) Meminta kepada beberapa peserta didik untuk menceritakan kembali inti dari tema pembelajaran dengan strategi broken text.

b) Memberikan inti sari atau ringkasan materi secara umum.

c) Pengajar mengevaluasi proses pembelajaran dari awal sampai akhir.

d) Memberikan motivasi kepada peserta didik, bahwa dalam pembelajaran membaca harus selalu aktif untuk melakukannya, baik dengan aktif membaca maupun aktif bekerja sama dengan teman.

e) Mengajak semua peserta didik untuk memberikan apresiasi kepada mereka semua dengan bertepuk tangan secara bergembira.

f) Mengajak peserta didik untuk menutup pembelajaran dengan berdoa setelah belajar.

g) Mendoakan peserta didik untuk kesuksesan mereka semua.

h) Menutup pembelajaran dengan mengucapkan salam.

b. Nilai-nilai karakter yang diintegrasikan dalam pembelajaran membaca Arab dengan strategi broken text

1. Tahap pra membaca (pendahuluan)

Pada tahapan ini, nilai karakter yang diintegrasikan adalah:

a) Religius, toleransi, bersahabat/komunikatif, dan cinta damai. Nilai karakter ini diintegrasikan melalui ucapan salam pengajar kepada peserta didik, doa bersama sebelum belajar, dan bacaan beberapa ayat al-Qur'an atau surat pendek pada juz 30.

b) Toleransi, cinta damai, dan komunikatif. Nilai karakter ini diintegrasikan melalui sapaan pengajar kepada peseta didik dengan pertanyaan kabar mereka.

c) Kerja keras dan jujur. Nilai karakter ini diintegrasikan melalui jawaban peserta didik atas pertanyaan pengajar tentang pelajaran yang sudah dipelajari, dan juga melalui jawaban peserta didik yang disampaikan kepada pengajar. Mereka tidak berbohong dengan apa 
yang diucapkan.

d) Disiplin dan fokus. Nilai karakter ini diintegrasikan melalui perhatian peserta didik atas apersepsi pengajar dengan cara mengaitkan materi yang sudah dipelajari dengan materi yang akan dipelajari, tujuan dan manfaatnya. Mereka dituntut untuk disiplin mendengarkan penjelasan tersebut.

e) Fokus, disiplin, peduli lingkungan, dan tanggung jawab. Nilai karakter ini diintegrasikan melalui perhatian mereka terhadap penjelasan pengajar tentang prosedur pembelajaran dengan strategi broken text.

2. Tahap membaca (kegiatan inti)

Pada tahapan ini, nilai karakter yang diintegrasikan adalah:

a) Disiplin, fokus, dan rasa ingin tahu. Nilai karakter ini diintegrasikan melalui konsentrasi peserta didik dalam mendengarkan bacaan pengajar tentang beberapa mufradāt (kosakata) yang belum diketahui oleh mereka.

b) Bertanggung jawab dan jujur. Nilai karakter ini diintegrasikan melalui jawaban peserta didik tentang pemahaman mereka.

c) Disiplin, kerja keras, dan Tanggung jawab. Nilai karakter ini diintegrasikan melalui kedisiplinan dan usaha peserta didik dalam membuka kamus jika terkendala dalam membaca teks.

d) Kreatif, komunikatif, disiplin, kerja keras, bersahabat, cermat, produktif, berani, toleransi, rasa ingin tahu, bertanggung jawab, dan gemar membaca. Nilai karakter ini diintegrasikan melalui partisipasi peserta didik dalam kegiatan membaca teks Arab dengan strategi broken text.

e) Kerja keras, berani, kreatif, dan bertanggung jawab. Nilai karakter ini diintegrasikan melalui usaha peserta didik untuk membacakan hasil bacaannya kepada semua teman-temannya, serta keikhlasan mereka untuk menerima evalusi dan masukan dari guru.

3. Tahap pasca-membaca (kegiatan penutup)

Nilai-nilai karakter yang bisa diintegrasikan pada tahapan ini adalah:

a) Kerja keras, komunikatif, jujur, fokus, dan disiplin. Nilai karakter ini diintegrasikan melalui kegiatan peserta didik untuk menceritakan kembali inti dari materi, serta kedisiplinan mereka dalam mendengarkan inti sari pembelajaran dari pengajar. 
b) Menghargai prestasidan bersahabat. Nilaikarakter ini diintegrasikan melalui pemberian apresiasi kepada mereka semua dengan bertepuk tangan secara bergembira.

c) Religius dan bersahabat. Nilai karakter ini diintegrasikan melalui pembacaan doa bersama setelah belajar.

d) Cinta damai, komunikatif dan bersahabat. Nilai karakter ini diintegrasikan melalui ucapan salam penutup oleh pengajar kepada peserta didik.

2. Pembelajaran membaca Arab dengan strategi peer teaching

Dalam peer teaching, ada seseorang atau beberapa orang peserta didik yang ditunjuk oleh pengajar sebagai pembantu pengajar dalam melakukan bimbingan terhadap teman sekelas. Tentu saja, peserta didik tersebut adalah mereka yang mempunyai keunggulan atau lebih baik keterampilan berbahasa Arabnya daripada teman-temannya. Dengan strategi aktif dan kreatif ini, peserta didik lebih mudah menerima keterangan yang diberikan oleh temannya yang lain karena tidak adanya rasa enggan atau malu bertanya, yang bermuara pada ketercapaian tujuan keterampilan membaca. Berkaitan dengan keterampilan membaca tersebut, diperlukan strategi peer teaching yang akan mendorong peserta didik untuk mengatur dan menguraikan apa yang telah mereka pelajari, di samping untuk menjelaskan materi kepada yang lainnya. Selain itu, peer teaching dapat meninggikan ikatan sosial pada diri peserta didik dalam kegiatan belajar.

a. Tahapan pembelajaran keterampilan membaca Arab dengan strategi peer teaching adalah:

1. Tahap pra membaca (pendahuluan)

Kegiatan yang dilakukan pengajar pada tahapan ini adalah:

a) Mengucapkan salam dan menyapa peserta didik dengan bertanya kabar mereka.

b) Mengajak peserta didik untuk berdoa sebelum belajar dan membaca beberapa ayat al-Qur'an atau membaca salah satu surat pendek dari juz 30.

c) Mengingatkan peserta didik bahwa pada saat itu akan belajar keterampilan membaca Arab.

d) Bertanya kepada beberapa peserta didik tentang pelajaran yang sudah dipelajari pada pertemuan sebelumnya.

e) Memberikan apersepsi dengan cara mengaitkan materi yang sudah 
dipelajari dengan materi yang akan dipelajari.

f) Menjelaskan topik dan tujuan pembelajaran, serta beberapa manfaat dari tema yang akan dipelajari dalam kehidupan peserta didik.

g) Menjelaskan kepada mereka bahwa akan belajar membaca Arab dengan strategi peer teaching atau belajar berkelompok dengan bimbingan teman sendiri.

h) Menjelaskan kepada peserta didik bahwa mereka harus bersikap aktif dan kreatif untuk membaca teks yang berhubungan dengan tema.

i) Setelah semua peserta didik paham dengan penjelasan pengajar, ia membagi peserta didik menjadi 4, 5, atau 6 kelompok.

j) Pengajar meminta peserta didik untuk berkumpul dengan kelompoknya masing-masing.

k) Pengajar menjelaskan bahwa dalam strategi peer teaching ini, setiap anggota kelompok harus aktif membaca teks dengan bimbingan temannya.

1) Menunjuk beberapa peserta didik untuk membimbing temantemannya dalam belajar membaca Arab. Pembimbing setiap kelompok boleh satu atau dua orang.

m) Menyiapkan sebuah teks bacaan yang akan dibaca sesuai tema.

n) Mengajak peserta didik untuk membaca basmalah dan memberikan apresiasi pada semuanya dengan bertepuk tangan.

2. Tahap membaca (kegiatan inti)

Pada tahapan membaca dengan strategi peer teaching ini, langkahlangkah yang harus dilalui oleh pengajar adalah:

a) Membacakan beberapa mufradāt (kosakata) yang belum diketahui oleh peserta didik dalam tema, dan menjelaskan maknanya.

b) Menanyakan kepada peserta didik tentang pemahaman mereka.

c) Meminta peserta didik untuk selalu membuka kamusnya jika terkendala dalam membaca teks.

d) Mengajak peserta didik untuk bersiap-siap memulai pembelajaran membaca Arab.

e) Membagikan teks bacaan kepada masing-masing kelompok.

f) Meminta kepada setiap peserta didik dalam kelompok untuk membaca teks. Di dalam kelompoknya mereka belajar dari dan dengan sesama teman lain dengan cara yang saling menguntungkan 
serta berbagi pengetahuan, ide, dan pengalaman masing-masing.

g) Memperhatikan antusiasme peserta didik, keaktifan dan kreativitas mereka.

h) Meminta kepada setiap anggota kelompok untuk memberikan tanggapan serta pendapat mereka sendiri yang nantinya akan disatukan dalam satu kesimpulan.

i) Meminta kepada setiap kelompok untuk merumuskan hasil diskusinya dalam satu kesimpulan atas dasar kesepakatan bersama.

j) Setelah kerja kelompok selesai, pengajar meminta masing-masing kelompok untuk mempresentasikan atau menyampaikan hasilnya ke depan kelas.

k) Meminta kepada kelompok lain untuk memberikan tanggapan (kritik, saran, pendapat, pertanyaan, komentar, dan lain sebagainya).

1) Mengajak peserta didik untuk berdiskusi tentang perbedaan pendapat sampai permasalahan terpecahkan.

m)Mencatat setiap masalah baru yang muncul dan memberikan solusinya.

n) Memberikan evaluasi dan klarifikasi terhadap hasil kerja kelompok tersebut, sehingga terjadi kesamaan pemahaman materi.

o) Memberikan apresiasi kepada semua peserta didik karena sudah belajar dengan aktif, kreatif, dan semangat.

3. Tahap pasca-membaca (kegiatan penutup)

Pada tahapan ini, langkah-langkah yang dilakukan oleh pengajar adalah:

a) Meminta kepada beberapa peserta didik untuk menceritakan kembali inti dari tema pembelajaran dengan strategi peer teaching.

b) Memberikan inti sari atau ringkasan materi secara umum.

c) Pengajar mengevaluasi proses pembelajaran dari awal sampai akhir.

d) Memberikan motivasi kepada peserta didik, bahwa dalam pembelajaran membaca harus selalu aktif untuk melakukannya, baik dengan aktif membaca maupun aktif bekerja sama dengan teman.

e) Mengajak semua peserta didik untuk memberikan apresiasi kepada mereka semua dengan bertepuk tangan secara bergembira.

f) Mengajak peserta didik untuk menutup pembelajaran dengan berdoa setelah belajar. 
g) Mendoakan peserta didik untuk kesuksesan mereka semua.

h) Menutup pembelajaran dengan mengucapkan salam.

b. Nilai-nilai karakter yang diintegrasikan dalam pembelajaran membaca Arab dengan strategi peer teaching

1. Tahap pra membaca (pendahuluan)

Pada tahapan ini, nilai karakter yang diintegrasikan adalah:

a) Religius, toleransi, bersahabat/komunikatif, dan cinta damai. Nilai karakter ini diintegrasikan melalui ucapan salam pengajar kepada peserta didik, doa bersama sebelum belajar, dan bacaan beberapa ayat al-Qur'an atau surat pendek pada juz 30.

b) Toleransi, cinta damai, dan komunikatif. Nilai karakter ini diintegrasikan melalui sapaan pengajar kepada peserta didik dengan pertanyaan kabar mereka.

c) Kerja keras dan Jujur. Nilai karakter ini diintegrasikan melalui jawaban peserta didik atas pertanyaan pengajar tentang pelajaran yang sudah dipelajari, dan juga melalui jawaban peserta didik yang disampaikan kepada pengajar. Mereka tidak berbohong dengan apa yang diucapkan.

d) Disiplin dan Fokus. Nilai karakter ini diintegrasikan melalui perhatian peserta didik atas apersepsi pengajar dengan cara mengaitkan materi yang sudah dipelajari dengan materi yang akan dipelajari, tujuan, dan manfaatnya. Mereka dituntut untuk disiplin mendengarkan penjelasan tersebut.

e) Fokus, disiplin, peduli lingkungan, dan tanggung jawab. Nilai karakter ini diintegrasikan melalui perhatian mereka terhadap penjelasan pengajar tentang prosedur pembelajaran dengan strategi peer teaching.

2. Tahap membaca (kegiatan inti)

Pada tahapan ini, nilai karakter yang diintegrasikan oleh pengajar adalah:

a) Disiplin, fokus, dan rasa ingin tahu. Nilai karakter ini diintegrasikan melalui konsentrasi peserta didik dalam mendengarkan bacaan pengajar tentang beberapa mufradāt (kosakata) yang belum diketahui.

b) Bertanggung jawab dan Jujur. Nilai karakter ini diintegrasikan melalui jawaban peserta didik tentang pemahaman mereka. 
c) Disiplin dan kerja keras. Nilai karakter ini diintegrasikan melalui kedisiplinan dan usaha peserta didik dalam membuka kamus jika terkendala dalam membaca teks.

d) Kreatif, komunikatif, disiplin, kerja keras, bersahabat, cermat, produktif, berani, toleransi, rasa ingin tahu, bertanggung jawab, dan gemar membaca. Nilai karakter ini diintegrasikan melalui partisipasi peserta didik dalam kegiatan membaca teks Arab dengan strategi peer teaching.

e) Kerja keras, berani, kreatif, jujur, dan bertanggung jawab. Nilai karakter ini diintegrasikan melalui usaha peserta didik untuk membacakan hasil bacaannya kepada semua temannya, serta keikhlasan mereka untuk menerima evalusi dan masukan dari pengajar.

3. Tahap pasca-membaca (kegiatan penutup)

Nilai-nilai karakter yang diintegrasikan pada tahapan ini adalah:

a) Kerja keras, komunikatif, jujur, fokus, dan disiplin. Nilai karakter ini diintegrasikan melalui kegiatan peserta didik untuk menceritakan kembali inti dari materi, serta kedisiplinan mereka dalam mendengarkan inti sari pembelajaran.

b) Menghargai prestasidan bersahabat. Nilaikarakterini diintegrasikan melalui pemberian apresiasi kepada mereka semua dengan bertepuk tangan secara bergembira.

c) Religius dan bersahabat. Nilai karakter ini diintegrasikan melalui pembacaan doa bersama setelah belajar.

d) Cinta damai, komunikasi, dan bersahabat. Nilai karakter ini diintegrasikan melalui ucapan salam penutup oleh pengajar kepada peserta didik.

\section{H. Penutup}

Seorang pengajar adalah ujung tombak pendidikan, ia harus mampu merevolusi mental peserta didiknya dengan baik, yaitu dengan mengubah cara pandang, pola pikir, sikap, nilai, dan perilaku mereka untuk mewujudkan negara yang berdaulat, mandiri, dan berkepribadian. Hal itu menjadi tanggung jawab semua pengajar mata pelajaran, termasuk pengajar bahasa Arab dalam keterampilan membaca Arab. 